\section{Italian research reorganization}

Sir-Your article on research in Italy $\mathrm{Na}$ ture, 323, 751; 1986) depicts the Italian government as working quickly at reorganizing the national research institutions.

As a researcher with 18 years' experience and an employee of the National Research Council (CNR) which, with its 6,189 employees, is the largest of the government research institutions, I would like to express my incredulity at the effects that this difficult reorganization will produce. By the time the reform of CNR is approved by parliament, the most talented and best qualified researchers will have fled to more remunerative positions in universities and industry.

It may be true, as reported in the article, that the average cost per researcher is about 130 million lire. (Please note that public research institutions in Italy employ a mere 14,000 of the 112,884 cited.) But the annual salary of a senior CNR researcher - whose competence, for the information of non-Italian readers, is at the level of a full professor at a university - is no less than 13 million lire, about $£ 6,500$.

It is with a sense of shyness mixed with a sprinkling of rage that we watch the CNR president, Professor Luigi Rossi-Bernardi, and the Minister of Research, Senator Luigi Granelli (whose joint efforts to save CNR must be acknowledged), praise the abundant productivity of CNR scientists

\section{Maori victory}

SIR-Whether or not he was summarizing the views expressed in Crosby's Ecological Imperialism, The Biological Expansion of Europe, 900-1900, Roy Porter (Nature 323, 587; 1986) shows extreme ignorance when he suggests that the Maori people of Aotearoa (New Zealand) "were stuck in the time-warp of the Stone Age and could not compete with European arms, ploughs and liquor". He also describes them as having been ruined by syphillis, a suggestion that might be equally appropriately applied to the English monarchy.

The Pakeha (European) myths about the land wars of last century have now been exposed. The British were defeated militarily by the Maori in spite of General Cameron's 18,000 men, the largest standing army at that time in the British Empire. The Maori applied lessons learned during their own musket wars to counter the superior fire power of mortars, rockets, howitzers and the 118pound Armstrong gun. The gunfighter's $p a$ (fortress) consisted of a system of trenches, parapets, rifle pits, covered walkways, fire-proofing and bomb shelters. The success of the Maori military strategy was evident at Gate $\mathrm{Pa}$ where Cameron suffered his heaviest defeat and concluded and the consequent healthy state of CNR. Most of us have spent several years abroad, often working in renowned international research centres, and are all aware of the conditions in which we continue to do research in Italy, and of how they compare with conditions in Britain, the United States and Japan.

Interestingly, the fate of CNR researchers and their hopes of better salaries now seem to be linked to the approval of a government bill (not the reform of CNR) originally devised to exempt the wages of workers at the Mint and of air traffic controllers from the restraints of the antiinflation finance law, which limits the increase of public employees' wages to 6 per cent a year.

It is well known that Italy suifers from frequent government reshuffles. Experienced observers think it likely that there will be another next March. Whereas I am sure that most of the many "million million" lire projects cited in your article will be funded, I doubt whether the contract for CNR employees (which expired on 31 December, 1984) will be renewed by the end of this year. \section{Institute of Protein Biochemistry \\ and Enzymology, CNR,}

Via Tioano, 6,

80072 Arco Felice, Naples, Italy

that New Zealand could not be taken by a war of attrition.

A more efficient way of getting Maori land was devised when the Maori Land Court was created and a system of individual ownership was installed to break up tribal lands. The war between Maori and Pakeha over the land and its resources was transferred to the arena of Pakehacreated courts, where it continues today.

The judgement that European domination of the globe is some kind of darwinian success story is premature. Maori resistance to imperialism has been so strong that the Pakeha population of Aotearoa has now been co-opted into the struggle. The parliament of New Zealand is about to pass a law that the governments of both the United Kingdom and the United States interpret as banning their navies from our harbours. We invite Alfred Crosby and Roy Porter to come to New Zealand and expand their view of global biopolitics, but we should warn them that they may catch the anti-nuclear bug which is said to be reaching epidemic proportions in this region.

\section{Department of Maori Studies,}

RANGINUI WALKER

Department of Physics,

University of Auckland,

Private Bag, Auckland, New Zealand

\section{Pan(da)selectionism}

SIR-I have been following with interest the recent correspondence in your pages on evolution, creation science and neodarwinsim. The letter from T.D. lles ${ }^{1}$, pointing out the regrettable habit of neodarwinians of making exclusive claims on the interpretation and exposition of evolutionary orthodoxy, was nicely complemented by the Commentary ${ }^{2}$ two weeks later on the ancestry of the giant panda. This article, written by a leading (indeed a founding) neo-darwinian, clearly shows the plasticity of neo-darwinian logic.

I do not wish to support either side in the argument over whether the giant pan$\mathrm{da}$ is more closely related to the raccoon or to the bear (indeed, this is the sort of argument that seems to excite the interest of neo-darwinians in particular: its significance for evolutionary theory in general is less clear), but instead to point out that Mayr's arguments concerning the data on haemoglobin amino-acid sequence differences are circular, self-serving and without experimental proof.

Mayr is concerned on the one hand to prove the irrelevance of the haemoglobin sequence data that show giant pandas to be more closely related to raccoons than to bears, and on the other hand to explain the near identity of the haemoglobin chains of humans and chimpanzees, despite an apparent evolutionary separation of over 10 million years. The explanation offered is, of course, selective pressure on haemoglobin. To quote: "In the case of man and chimpanzee this influence has been conservative, but in the case of the bears it might well have been centrifugal".

What can one say about such ad hoc panselectionist arguments that are not supported by biochemical data plausibly relating haemoglobin structure and function to the physiology, habits and behaviour of pandas, raccoons, bears or primates? It is clear that faith in natural selection alone can explain all in these sermons from the pulpit of neo-darwinism. It is surely time to acknowledge that gene and protein sequence data often support theories of molecular evolution in which natural selection of variants is not explanatory ${ }^{3}$, or in which common molecular ancestry is disputed ${ }^{4}$, and that the use of these data to support either molecular-clock based phylogenetic trees or neo-darwinism selectionist explanations of evolution should be treated with appropriate scepticism.

GREGORY W. WARR

Department of Biochemistry,

Medical University of South Carolina,

171 Ashley Avenue, Charleston, North Carolina 29425-2211, USA

Iles, T.D. Nature 323, 576 (1986)

2. Mayr, E. Nature 323, 769-771 (1986).

. Dover, G.A. \& Flavell, R.B. Cell 38, 622-623 (1984)

4. Schwabe, C. Trends biochem. Sci. 11, 280-283 (1986). 